\title{
Evaluation of antioxidant and cytotoxic properties of Vernonia amygdalina
}

\author{
Omede $\mathrm{A}^{1 *}$, Suleiman $\mathrm{MS}^{1}$, Atanu FO ${ }^{1}$, Momoh $\mathrm{S}^{1}$, Friday $\mathrm{ET}^{2}$, Sheneni VD ${ }^{1}$, Jegede ER \\ ${ }^{1}$ Department of Biochemistry, Kogi State University, Nigeria \\ ${ }^{2}$ Department of Medical Biochemistry, Kogi State University, Nigeria
}

Submission: January 12, 2018; Published: May 23, 2018

*Corresponding author: Omede Ameh, Department of Biochemistry, Faculty of Natural Sciences, Kogi State University, PMB 1008, Anyigba, Nigeria, Tel: +234-9080163653; Email: omedeameh@gmail.com

\begin{abstract}
The present investigation was carried out to evaluate the antioxidant activity and cytotoxic properties of Vernonia amygdalina. The free radical scavenging activity using a stable radical; 2, 2-Diphenyl-1-picryl hydrazyl, lipid peroxidation assay (DPPH), and nitric oxide inhibitory assay gave the highest percentage inhibition as $74.55 \pm 1.07 \% ; \mathrm{IC}_{50}=1.831,60.42 \pm 0.11 ; \mathrm{IC}_{50}=3.84 \pm 1.03$ and $71.26 \pm 0.48 ; \mathrm{IC}_{50}=0.99 \mathrm{mg} / \mathrm{ml}$, respectively. This is comparable to the standards quercetin used ( $P>0.05$ ). In addition; total phenol, total flavoniods, anthocyanin and proanthocyanidine of the extract were determined using established methods. The results obtained justify the scavenging activity of the extracts. Furthermore, the extracts possessed very low cytotoxicity to brine-shrimp lethality test, when compared with the reference standard (Potassium dichromate, $\mathrm{LC}_{50}$ $=0.003 \pm \mu \mathrm{g} / \mathrm{mL}$ ). The results obtained in the study indicate that $V$. amygdalina can be a safe potential source of natural antioxidant agent; used as a neutralcetical/functional food..
\end{abstract}

Keywords: 2; 2-Diphenyl-1-picryl hydrazyl; Antioxidant; Cytotoxicity; Veronia amygdalinais

\section{Introduction}

Vernonia amygdalina is a shrub that grows predominantly in the tropical Africa. Leaves from this plant serve as food vegetable and culinary herb in soup [1]. Anecdotal evidences suggest the use of $V$. amygdalina in the treatment of feverish condition, cough, constipation, hypertension and related vascular diseases as well as diabetes. Photochemical screening of this plant leaves extracts showed the presence of Saponins, riboflavin, polyphenols, sesquiterpene and flavonoids [2]. Strong antioxidant activities involving flavonoids extracted from $V$. amygdalina and its saponins have been reported to elicit anti-tumoral activities in leukemia cells [3]. In addition, peptides from $V$. amygdalina are known to be potent inhibitor of mitogen activated protein kinase (MAPK) which is involved in the regulation and growth of breast tumour [4].

Previous studies have shown that a good number of plants have antioxidant activities that could be therapeutically beneficial. Consequently, antioxidant agents of natural origin have attracted special interest because of the potential they hold in the maintenance of health and protection of some age related degeneration disorders, such as coronary heart disease and cancer, neurodegenerative disease [5-7].

Although, antioxidants from natural sources are beneficial, it is pertinent to know their bio-safety. In this regard, the brine shrimp lethality assay is considered a useful tool for preliminary assessment of toxicity of plant extracts; a suggested pharmaco logical screening method in plant extracts. It has been used for the detection of fungal toxins, plant extract toxicity. The shrimp lethality assay was proposed by Michael and co-workers in 1956, and later developed by Vanhaecker and his group in 1981. This is based on the principle, whereby the kill laboratory-culture of an invertebrate, Artemia salina L (the brine shrimp larva) following exposure to a varied concentration of plant extracts, heavy metals, cyan bacteria toxins and pesticides, is assessed for toxicity [8]. The purpose of this study is to evaluate the acute toxicity and antioxidant properties of $V$. amygdalina in relation to its use as a neutralcetical.

\section{Materials and Methods}

V. Amygdalina: Fresh leaves of V. amygdalina were collected from the University Village, Kogi State University, Nigeria. The plant material was identified and authenticated by taxonomist in the Department of Botany, Kogi State University, where the voucher specimen (VA-111) was deposited. Fresh leaves of V. amygdalina were air dried under room temperature until a constant weight was obtained. Thereafter, the leaves were milled to a coarse powder with the use of laboratory Mortar and Pestle. After this, 20g of the plant powder was weighed into a volumetric flask and then extracted using $200 \mathrm{mls}$ of distilled water for 72 hours. The crude extract was obtained by concentrating the water soluble extract using rotary evaporator at $45^{\circ} \mathrm{C}$. The working solution of extract 
was prepared by weighing out $0.02 \mathrm{~g}$ of crude extract accurately and dissolved it in $20 \mathrm{ml}$ of distilled water to give an effective concentration of $1 \mathrm{mg} / \mathrm{ml}$.

\section{Radical scavenging activity}

In order to determine the antioxidant properties of the plant radical scavenging activities of the leaves extract, was determined using the stable radical DPPH (2, 2-diphenyl-1 piccrlhydrazyl hydrate) according to the method of Blois (1958) as describe by Babalola and co-workers [9]. The principle is based on the reaction of DPPH, and an antioxidant compound to generate hydrogen, which is reduced (DPPH $+\mathrm{RH} \rightarrow \mathrm{DPPH} 2+\mathrm{R})$. The observed colour change from deep violet to light yellow was measured at $517 \mathrm{~nm}$. To $1 \mathrm{ml}$ of varied concentrations $(0.5,0.25,0.125,0.0625$, $0.003125 \mathrm{mg} / \mathrm{ml}$ ) of the extract or standard, was added $1 \mathrm{ml}$ of $0.3 \mathrm{mM}$ DPPH in methanol. The mixture was vortexed, and then incubated in a dark chamber for 30 minutes. Thereafter the absorbance was read at $517 \mathrm{~nm}$ against a DPPH control containing only $1 \mathrm{ml}$ of methanol in place of the extract. The antioxidant activity (AA) was then calculated using the formula:

$$
\mathrm{AA}=[(\mathrm{Ao}-\mathrm{Ac}) / \mathrm{Ao}] \times 100,
$$

Where: Ao = absorbance without extract and Ac $=$ absorbance with extract.

\section{Nitric oxide}

Sodium nitroprusside generates nitric oxide in aqueous solution at Physiological $\mathrm{pH}$, which consequently interacts with oxygen to produce nitric ions. This was measured by Griess reaction [10].

Procedure: $3 \mathrm{ml}$ of the reaction mixture containing sodium nitroprusside $(10 \mathrm{mM})$ in phosphate buffered saline (PBS) together with the varying concentrations of the extract $(0.5,0.25,0.125$, $0.0625,0.003125 \mathrm{mg} / \mathrm{ml}$ ) were incubated in a water bath at room temperature for 150 minutes. This was followed by the removal of $1.5 \mathrm{ml}$ of the reaction mixture and the addition of $1.5 \mathrm{ml}$ of Griess reagent. After which, the absorbance of the chromophore formed was read using spectrophotometer at $546 \mathrm{~nm}$. Percentage inhibition of nitric oxide radical by the extract was calculated using the formula:

$$
\mathrm{NO}=[(1-\mathrm{E} / \mathrm{C})] \times 100,
$$

Where: $\mathrm{C}=$ absorbance value of the fully

\section{Ferric reducing antioxidant power assay (FRAP) assay}

The FRAP assay used antioxidants as reductant in a redox linked colorimetric method with absorbance measured with a spectrophotometer. A $300 \mathrm{mmol} / \mathrm{L}$ acetate buffer of $\mathrm{pH} 3.6$ (3.1g of sodium acetate $+16 \mathrm{ml}$ of glacial acetic acid made up to $1 \mathrm{~L}$ with distilled water, 10mmol/L 2, 4, 6-tri (2-pyridyl 1, 3, 5-triazine, 98\% (sigma-Aldrich) $(3.1 \mathrm{mg} / \mathrm{ml}$ in $40 \mathrm{mmol} / \mathrm{L} \mathrm{HCl}$ ) and $20 \mathrm{mmol} / \mathrm{L} \mathrm{of}$ ferric chloride were mixed together in the ratio of 10:1:1, respectively to give the FRAP working reagent.
Procedure: A $50 \mu \mathrm{L}$ aliquot of extract was added to $1.5 \mathrm{ml}$ of FRAP reagent in a semi-micro plastic cuvette. Absorbance measurement was taken at $593 \mathrm{~nm}\left(\mathrm{~A}_{593}\right)$ exactly 10 minutes after mixing using $50 \mu \mathrm{L}$ of water as the reference. Thereafter, to standardize $50 \mu \mathrm{L}$ of the standard, iron (III) sulphate, $(1 \mathrm{mM})$ was added to $1.5 \mathrm{ml}$ of FRAP reagent. All measurement was taken at room temperature in the absence of light.

\section{Evaluation of total phenolic content}

The total phenolic of V.amygdalina extract was determined using the folin ciocalten assay method of Singleton and Rossi (1965) [11]. To $0.1 \mathrm{ml}$ of $1 \mathrm{mg} / \mathrm{ml}$ of extract /standard was added $0.9 \mathrm{ml}$ of distilled water. Thereafter, $0.2 \mathrm{ml}$ of folic reagent was added. This was vortex-missed. Subsequently, $1 \mathrm{ml}$ of $7 \% \mathrm{Na}_{2} \mathrm{CO}_{3}$ solution was added to the mixture after 5 minutes. The solution was followed by dilution to $2.5 \mathrm{ml}$ and then incubated for 90 minutes at room temperature. The absorbance was read at $750 \mathrm{~nm}$ against the reagent blank. Standard preparation was carried out by preparing a stock solution of gallic acid ( $1 \mathrm{mg} / \mathrm{ml})$ aliquots of $0.2,0.4,0.6,0.8$ and $1 \mathrm{ml}$ were taken and made up to a total volume of $2 \mathrm{ml}$.

With the equation as shown below, the total phenolic content of the plants was then calculated, and expressed as mg gallic acid equivalent (GAE)/g fresh weight. The analysis was carried out in triplicates.

$$
\text { Equation (1) - - - - } \mathrm{C}=\mathrm{c} * \mathrm{v} / \mathrm{m}
$$

Where: $\mathrm{C}=$ total content of phenolic compound in gallic acid equivalent (GAE); $c$ = concentration of gallic acid established from the calibration curve, $\mathrm{mg} / \mathrm{ml} ; \mathrm{V}=$ volume of extract $(\mathrm{ml}) ; \mathrm{m}=$ Weight of the crude methanolic plant obtained

\section{Evaluation of total flavonoids content}

Aluminium chloride colorimetric method described by Zhilen was used for the determination of the total flavonoidal content of the plant extract [5]. Water $(0.4 \mathrm{ml})$ was added to $0.1 \mathrm{ml}$ of extract/ standard, as well as $0.1 \mathrm{ml}$ of $5 \%$ sodium nitrite. This was left for 5 minutes. Thereafter, $0.1 \mathrm{ml}$ of $10 \%$ aluminium chloride and 0.2 $\mathrm{ml}$ of sodium hydroxide was added to the solution, and the volume was adjusted to $2.5 \mathrm{ml}$ with water. The absorbance at $510 \mathrm{~nm}$ was measured against the blank.

\section{Standard preparation}

A stock solution of quercetin $(1 \mathrm{mg} / \mathrm{ml})$ was prepared. Aliquots of $0.2,0.4,0.6,0.8$, and $1 \mathrm{ml}$ were taken and the volume made up to $2 \mathrm{ml}$ with distilled water.

The total flavonoid content of the plant extract was then calculated as shown in the equation below and expressed as mg quercetin equivalents per gram of the plant extract. The analysis was conducted duplicates and mean value considered. $X=q \times V / w$ : Where $\mathrm{X}=$ total content of flavonoid compound in quercetin equivalent; $\mathrm{q}=$ concentration of quercetin established from the standard curve; V=volume of extract $(\mathrm{ml}) ; \mathrm{w}=$ weight of the crude methanolic extract obtained. 


\section{Proanthocyanidin content determination}

The proanthocyanidin content of the extract was determined spectrophotometrically [12]. Extracts were diluted to provide a spectrophometric reading between 0.1 and 0.8 absorbance units.

Procedure:A $0.25 \mathrm{ml}$ sample aliquot of adequately diluted extract was added to $2.25 \mathrm{ml}$ of concentrated hydrochloric acid in n-butanol $(10 / 90, v / v)$ in a screw top vial. The resulting solution was mixed for 10 to 15 seconds. Extracts were then heated for 90 minutes in an $85{ }^{\circ} \mathrm{C}$ water bath then cooled to $15-25{ }^{\circ} \mathrm{C}$ in an ice bath. The absorbance at $550 \mathrm{~nm}$ was measured on a UV visible spectrophotometer. A control solution of each extract was prepared to account for background absorbance due to pigments in the extracts. The control solution consisted of the diluted extract prepared in the hydrochloric acid/n-butanol solvent without heating.

The proanthocyanidin content was expressed as mg cyaniding per Kg of sample.

$$
=\frac{(\Delta \mathrm{A} \times \mathrm{MW}) \times \mathrm{DF} \times 1000}{\epsilon \times \mathrm{L}}
$$

Where:

$$
\begin{aligned}
& \Delta \mathrm{A}=\mathrm{A}_{550 \text { sample }}-\mathrm{A}_{550 \text { control }} \\
& \text { A550 sample = Sample absorbance at } 550 \mathrm{~nm} \\
& \text { A550control = control sample absorbance at } 550 \mathrm{~nm} \\
& \epsilon=\text { Molar absorbance co efficient of cyanidin }(17,360 \mathrm{~L}-1 \mathrm{M}- \\
& \left.1 \mathrm{~cm}^{-1}\right) \\
& \mathrm{L}=\text { pathlenght }(1 \mathrm{~cm}) \\
& M W=\text { Molecular weight of cyaniding }(287 \mathrm{~g} / \mathrm{mol}) \\
& D F=\text { dilution factor to express as } \mathrm{g} / \mathrm{L} \\
& 1000 \text { is the conversion from grams to milligram }
\end{aligned}
$$

\section{Determination of total anthocyanin content}

Total anthocyanin content of the extract was determined by the $\mathrm{pH}$ differential method [13].

Procedure:A pH 1.0 buffer solution was prepared by mixing $125 \mathrm{ml}$ of $0.2 \mathrm{~N} \mathrm{KCl}$ with $385 \mathrm{ml}$ of $0.2 \mathrm{~N} \mathrm{HCl}$ and $490 \mathrm{ml}$ of distilled water. The $\mathrm{pH}$ of the buffer was adjusted to $\mathrm{pH} 1.0$ with $0.2 \mathrm{~N} \mathrm{HCl}$.A $\mathrm{pH} 4.5$ buffer solution was prepared by mixing $440 \mathrm{ml}$ of $1.0 \mathrm{M}$ sodium acetate with $200 \mathrm{ml}, 1.0 \mathrm{M} \mathrm{HCl}$ and $360 \mathrm{ml}$ of distilled water. The $\mathrm{pH}$ of the solution was measured and adjusted to $\mathrm{pH} 4.5$ with $1.0 \mathrm{MHCl}$.

$0.5 \mathrm{ml}$ of the extract was diluted to $12.5 \mathrm{ml}$ in the $\mathrm{pH} 1.0$ and 4.5 buffers, and allowed to equilibrate in the dark for 2 hours. The absorbance of the samples at 512nm (A512nm) and 700nm (A700nm) was measured on a UV- visible spectrophotometer. The difference in absorbance $(\Delta \mathrm{A})$ between the anthocyanin extract diluted in $\mathrm{pH} 1.0$ and $\mathrm{pH} 4.5$ buffers was calculated using the equation below

$$
\begin{gathered}
\Delta \mathrm{A}=(\mathrm{A} 512 \mathrm{pH} 1.0-\mathrm{A} 700 \mathrm{~nm} \mathrm{pH} 1.0)-(\mathrm{A} 512 \mathrm{~nm} \mathrm{pH} 4.5-\mathrm{A} 700 \mathrm{~nm} \\
\mathrm{pH} 4.5)
\end{gathered}
$$

The A700nm was employed in the calculation of $\Delta \mathrm{A}$ to correct for any background absorbance due to turbidity on the extracts. The anthocyanin content was expressed as mg cyaninidin 3-glucoside per $100 \mathrm{~g}$ berries using a molar absorbance co efficient $(\epsilon)$ of $26900 \mathrm{~L}^{-1} \mathrm{M}^{-1} \mathrm{~cm}^{-1}$ (Guisti and Wrolstad, 2001).

$$
\begin{gathered}
\mathrm{TACY}=(\Delta \mathrm{A} \times \mathrm{MW}) \times \mathrm{DF} \times 1000 \\
\epsilon \times 0.1 \times 1
\end{gathered}
$$

Where:

TACY = Total anthocyanin expressed as mg cyaniding 3-glucoside $/ 100 \mathrm{~g}$ of plant material

MW= molecular weight of cyaniding 3-glucoside (449.2g/L)

$\mathrm{DF}=$ dilution factor to expressed the extracts on per gram of plant basis

$\epsilon=$ molar absorption co efficient of cyaniding 3-glucoside $\left(26900 \mathrm{M}^{-1} \mathrm{~cm}^{-1}\right)$

$0.1=$ is the conversion factor for per 1000 grams to 100 grams basis.

\section{Brine shrimp bioassay}

Brine shrimp lethality test was carried out using hatched Brine shrimp (Artemia salina L) larvae (nauplii) according to the procedure described by The eggs were hatched in artificial sea water (16g of sea salt in $50 \mathrm{ml}$ of distilled water) by adding $100 \mathrm{mg}$ of brine shrimp eggs to $50 \mathrm{ml}$ of sea water that was partitioned into two compartments. The compartment sprinkled with the cysts was left dark, while the other compartment was supplied with bright white fluorescent light. After 24hours of incubation, the hatched shrimps moved to the illuminated side. Ten brine shrimps larvae were then counted and transferred to each sample vial, using a Pasteur pipette and artificial sea water was added to make $10 \mathrm{ml}$. The sample vials were previously containing solution of the extract prepared by dissolving $0.2 \mathrm{~g}$ of the extract in $20 \mathrm{ml}$ distilled water to give concentration of $1 \mathrm{mg} / \mathrm{ml}$. The varied concentrations from the stock solution were transferred to different graduated container with the aid of a micropipette. The survivors were counted after 24 hours. Three independent studies were carried out $(\mathrm{n}=3)$.

\section{Statistical Analysis}

The results are expressed as mean \pm SEM using Graph Pad Prism Graphical-Statistical Package version 5. The difference between groups was analyzed by Student t-test followed by Dennett's test with $5 \%$ level of significance $(\mathrm{p}<0.05)$.

\section{Results}

\section{Antioxidants}

The extract was assayed for total content of four major types of antioxidant properties. The antioxidant constituents were: to- 


\section{International Journal of Cell Science \& Molecular Biology}

tal phenol, total flavonoid, proanthocyanidins and anthocyanins. However, the percentage yield of the crude extract used for the assays is given as $10.11 \pm 1.08 \%$. The results showed the total phenolic content as $1.588 \pm 0.04 \mathrm{mgGAE} / \mathrm{g}$, which is considerably high compared to the standard. The total flavonoid content expressed as quercetin equivalent per gram of the plant extract showed that the test material had $0.857 \pm 0.15 \mathrm{mg}$ QUE/g dry weight for the crude extract (Table 1). These two indices are pointer to an increased antioxidant activity. The concentration of anthocyanin in the sample was $0.099 \pm 0.08$ cyanidin 3-glucoside $/ 100 \mathrm{~g}$ for the crude extract, while the concentrations of proanthocyanin was $0.038 \pm 0.05$ cyanidin 3 -glucoside $/ 100 \mathrm{~g}$ for the crude extract. Tannin was also assayed, and it gave a concentration of $1.188 \pm 0.04 \mathrm{mg} / \mathrm{ml}$ (Table 1 ).

Table 1: Concentration of some Antioxidant constituents contained in $\checkmark$. amygdalina leaves.

\begin{tabular}{|c|c|}
\hline Constituents & Crude Extract \\
\hline Total phenol (mg GAE/g dry wt) & $1.588 \pm 0.04$ \\
\hline Total flavonoids (mg QUE/g) dry wt) & $0.857 \pm 0.15$ \\
\hline Anthocyanin (ng cyanidine chloride/g dry wt) & $0.099 \pm 0.08$ \\
\hline Proanthocy (ng cyanidine chloride/g) dry wt) & $0.038 \pm 0.05$ \\
\hline Tannins & $1.188 \pm 0.04$ \\
\hline
\end{tabular}

All values are expressed as mean \pm SEM $(n=3)$

\section{Antiradicals}

The result of the antiradical assays carried out on the extract is shown in Table 2. Using the DPPH (2, 2-diphenyl-1-piccrlhydrazyl hydrate) assay, a well established antiradical assay, the activity was concentration dependent i.e. activity increases with increase in concentration. The extract gave the highest inhibition of $74.55 \pm 1.07 \%$ at $0.005 \mathrm{mg} / \mathrm{ml}$. The calculated $\mathrm{IC}_{50}$ values for the test extract and standard Quercetin were $1.831 \pm 0.15$ and $0.00326 \pm 0.24 \mathrm{mg} / \mathrm{ml}$, respectively Table 2 . The extract used showed activity despite the significant difference $(\mathrm{P}<0.05)$ between the test and standard.

Table 2: DPPH radical scavenging activity of $V$. amygdaline leaves extract and the standard antioxidant, quercetin.

\begin{tabular}{|c|c|c|}
\hline $\begin{array}{c}\text { Concentrations } \\
\text { (mg/ml) }\end{array}$ & $\begin{array}{c}\text { Percentage In- } \\
\text { hibition (\%) for } \\
\text { Quercetin }\end{array}$ & $\begin{array}{c}\text { Percentage Inhi- } \\
\text { bition (\%) for } \boldsymbol{V} \\
\text { amygalina }\end{array}$ \\
\hline 0.005 & $68.91 \pm 0.47$ & $74.55 \pm 1.07$ \\
\hline 0.0025 & $44.91 \pm 0.82$ & $68.28 \pm 0.46$ \\
\hline 0.00125 & $28.34 \pm 1.23$ & $59.69 \pm 0.78$ \\
\hline 0.000625 & $17.89 \pm 0.15$ & $48.11 \pm 0.05$ \\
\hline 0.0003125 & $6.55 \pm 2.06$ & $28.99 \pm 0.61$ \\
\hline $\mathrm{IC}_{50}$ & $0.00326 \pm 0.24 \mathrm{mg} / \mathrm{ml}$ & $1.831 \pm 0.15 \mathrm{mg} / \mathrm{ml}$ \\
\hline
\end{tabular}

All values are expressed as mean \pm SEM $(n=3)$. The level of activity between the crude extract and the standard Quercetin is significantly different $(p<0.05)$
Table 3: Nitric oxide radical inhibition properties of V.amygdalina leaves crude extract.

\begin{tabular}{|c|c|}
\hline Concentration $(\mathbf{m g} / \mathbf{m l})$ & Crude Extract \\
\hline 0.5 & $60.42 \pm 0.11$ \\
\hline 0.25 & $51.06 \pm 0.04$ \\
\hline 0.125 & $37.16 \pm 0.05$ \\
\hline 0.0625 & $30.01 \pm 0.21$ \\
\hline 0.03125 & $20.93 \pm 0.34$ \\
\hline $\mathrm{IC}_{50}(\mathrm{mg} / \mathrm{ml})$ & $3.84 \pm 1.03$ \\
\hline
\end{tabular}

All values are expressed as mean $\pm \operatorname{SEM}(n=3)$.

Table 4: FRAP assay depicting the antioxidant potential of V.amygdalina leaves crude extract.

\begin{tabular}{|c|c|}
\hline Concentration $(\mathbf{m g} / \mathbf{m l})$ & Crude Extract \\
\hline 0.5 & $1.199 \pm 0.04$ \\
\hline 0.25 & $0.876 \pm 0.08$ \\
\hline 0.125 & $0.702 \pm 0.12$ \\
\hline 0.0625 & $0.564 \pm 0.16$ \\
\hline 0.03125 & $0.348 \pm 0.09$ \\
\hline
\end{tabular}

All values are expressed as mean $\pm \operatorname{SEM}(n=3)$.

The nitric oxide inhibition assay also showed that Vamygdalina is a potent scavenger of nitric oxide as shown by the percentage inhibition and $\mathrm{IC}_{50}$ of $3.84 \pm 1.03 \mathrm{mg} / \mathrm{ml}$ Table 3 . The FRAP assay result showed a concentration dependent change when the FRAP values of the test fractions were determined. Results were expressed in mmol $\mathrm{Fe}^{2+} / \mathrm{L}$. The concentration of $\mathrm{Fe}^{2+}$ in the reaction mixture at $0.5 \mathrm{mg} / \mathrm{ml}$, was given as $1.49 \pm 0.18 \mathrm{mmol} \mathrm{Fe}^{2+} / \mathrm{l}$ for the test extract (Table 4).

\section{Brine shrimp lethality test}

As shown in Table 5, the plant extract showed the highest percentage lethality to be $75 \%$ with $\mathrm{LC}_{50}$ of $1.49 \mathrm{mg} / \mathrm{ml}$, whereas, the $\mathrm{LC}_{50}$ for the positive standard $\left(\mathrm{K}_{2} \mathrm{Cr}_{2} \mathrm{O}_{7}\right)$ was found to be $10.91 \pm 2.22 \mu \mathrm{g} / \mathrm{ml}$. The plant extract showed concentration at $50 \%$ percentage lethality to be a little greater than $1 \mathrm{mg} / \mathrm{ml}$ compared to the standard. In essence, the test sample at the concentration used could be harmless to the biological system. All values are expressed as mean $\pm S E M$. This result is a triplicate of three independent experiments.

Table 5: The cytotoxic effect of V.amygdalina leaves extract on Brine shrimps.

\begin{tabular}{|c|c|}
\hline Concentration $\mathbf{( m g} / \mathbf{m l})$ & Percentage Lethality (\%) \\
\hline 1 & $75 \pm 2.35$ \\
\hline 0.5 & $65 \pm 2.04$ \\
\hline 0.25 & $50 \pm 1.17$ \\
\hline 0.125 & $40 \pm 2.04$ \\
\hline 0.0625 & $20 \pm 2.35$ \\
\hline $\mathrm{LC}_{50}$ & $1.49 \pm 0.19 \mathrm{mg} / \mathrm{ml}$ \\
\hline
\end{tabular}

\section{Discussion}

Studies have shown that consumption of biosafe exogenous and natural antioxidant is beneficial, as regard combating diseas- 
es such as cancer, arthritis, diabetes, among others. These diseases emanates from oxidative stress mostly caused by reactive oxygen species (ROS) [14-16]. Moreover, synthetic antioxidant, including tert-butylhydroquinone (TBHQ), buthylatedhydroxytoluene (BHT) and propylgallate have been found to be beneficial, but toxic, as well as with attendant effects $[17,18]$. This is shown by comparing the bio-safe syzygium cumini fruit juice, a natural antioxidant to the toxic BHT on serum enzymes such as ALT (alanine transferase), AST (aspartate transferase), alkaline phosphatase and urea in rats [19]. For this reason, it has become imperative to continue to investigate and search for more bio-safe antioxidants that could be relevant in the fight against oxidative stress V. amygdalina is useful in this regard [20-22]. Kahaliw and his group have reported on the biosafety of this plant [23]. Moreover, anecdotal evidence attests to its use in the treatment of different ailments after boiling, as well as its use in the preparation of soup. This informed the aqueous extraction carried out, as opposed to the use of organic solvents, such as methanol and ethanol.

This beneficial antioxidants; Phenols, flavonoids, proanthocyanidine and anthocyanin, amongst others, contains hydroxyl groups known for scavenging free radicals [24-26]. Phenolic compounds as antioxidants act as free radical chain reaction terminator. This combat oxidative stress responsible for neurodegenerative and cardiovascular diseases. Phenolic compounds constitute a large group of biologically active substances, such as Quercetin, catechin, ferrulic acid, caffeic acid, gallic acid, coumaric acid, and rutin. These are naturally occurring antioxidants. Even though the scavenging activity of the extract is not as high as the control, quercetin, the results suggest the presence of phenolics provided the active DPPH scavenging activity. The flavonoid content could have also provided the scavenging activity, as the activity-driven mechanisms of flavonoid are via chelating and scavenging process. It has been established that $V$. amygdalina contains these antioxidant agents $[27,28]$, which is similar to the results in table 4. The slight differences observed, could be due to the polarity of the solvents used. A less polar solvent like methanol and ethanol would extract more antioxidant component of the plant compared to the water used. This properties and the report of Yagi and Khiralla qualifies this plant as a neutralcetical [28].

A lot has been reported on V. amygdalina as a functional food. In order to further establish its biosafety, the result in table 5 and the work of Kaali justifies V. amydalina as an anti-malaria agent that is biosafe for all the benefits discoursed above [29]. The study of Patnaik and Bhatnagar is in agreement with this study [30]. Moreover, Thompson showed comparable results [31] Data from alcoholic extract of Vamygdalina [32,33] is statistically indistinguishable compared to this study (Table 5).

\section{Conclusion}

On the basis of the data from this current research, V. amygdalina is a potent antioxidant attributable to their flavanoid and phenolic constituent that is biosafe for all the health benefits that is known for.

\section{References}

1. Adaramoye OA, Akintayo O, Achem J, Fafunso MA (2008) LipidLowering Effects of Methanolic Extract of Vernonia Amygdalina Leaves In Rats Fed on High Cholesterol Diet. Vasc Health Risk Manag 4: 235241.

2. Atangwho I, Ebong P, Eyong E, Williams I, Eten M, et al. (2009) Comparative Chemical Composition of Leaves of Some Antidiabetic Medicinal Plants: Azadirachta Indica, Vernonia Amygdalina and Gongronema Latifolium. African Journal of Biotechnology 18: 8 .

3. Adaramoye O, Ogungbenro B, Anyaegbu O, Fafunso M (2008) Protective Effects of Extracts of Vernonia Amygdalina, Hibiscus Sabdariffa And Vitamin C Against Radiation-Induced Liver Damage In Rats. Journal of Radiation Research 49(2): 123-131.

4. Usunomena U (2014) Antihepatotoxic Efficacy of Vernonia Amygdalina Ethanolic Leaf Extract on Dimethylnitrosamine (Dmn)-Induced Liver Damage In Rats. International J of Healthcare and Biomedical Research 3: 89-98.

5. Kakkar S, Bais S (2014) A Review on Protocatechuic Acid And Its Pharmacological Potential. Isrn Pharmacology.

6. Albarracin SL, Stab B, Casas Z, Sutachan JJ, Samudio I, et al. (2012) Effects Of Natural Antioxidants In Neurodegenerative Disease. Nutr Neurosci 15: 1-9.

7. Chandel NS, Tuveson DA (2014) The Promise And Perils Of Antioxidants For Cancer Patients. New England Journal of Medicine 371: 177-178.

8. Nguta J, Mbaria J, Gakuya D, Gathumbi P, Kabasa J, et al. (2012) Evaluation Of Acute Toxicity Of Crude Plant Extracts From Kenyan Biodiversity Using Brine Shrimp, Artemia salina L.(Artemiidae). Open Conf Proc J: 30-34.

9. Babalola O, Agbi J, Badiora A, Areola O (2016) Protective Effects Of Solanum erianthum D. Don Leaf Extract On Lead-Induced Toxicity In Adult Wistar Rats.

10. Agarwal R, Gupta S, Agarwal P, Srivastava S, Alyayutdin R (2013) Anticholinesterase, Antioxidant And Nitric Oxide Scavenging Activity of The Aqueous Extract of Some Medicinal Plants. British Journal of Pharmaceutical Research 3: 807.

11. Gülçin I (2012) Antioxidant Activity of Food Constituents: An Overview. Arch Toxicol 86: 345-391.

12. Gunaratne A, Wu K, Li D, Bentota A, Corke H, et al. (2013) Antioxidant Activity And Nutritional Quality Of Traditional Red-Grained Rice Varieties Containing Proanthocyanidins. Food Chem 138: 1153-1161.

13. Inácio MRC, De Lima KMG, Lopes VG, Pessoa JDC, De Almeida, et al. (2013) Total Anthocyanin Content Determination in Intact Açaí (Euterpe Oleracea Mart.) and Palmitero-Juçara (Euterpe Edulis Mart.) Fruit Using Near Infrared Spectroscopy (Nir) and Multivariate Calibration. Food Chem 136: 1160-1164.

14. Li H, Horke S, Förstermann U (2013) Oxidative Stress in Vascular Disease and Its Pharmacological Prevention. Trends Pharmacol Sci 34: 313-319.

15. Omede A (2016) Total Polyphenolic Content And Antioxidant Properties of Moringa Oleifera Leaf Extracts. Animal Research International 13: 2454.

16. Mastrogiacomo D, Lenucci MS, Bonfrate V, Di Carolo M, Piro G (2015) Lipid/Detergent Mixed Micelles As A Tool For Transferring Antioxidant Power From Hydrophobic Natural Extracts Into BioDeliverable Liposome Carriers: The Case Of Lycopene Rich Oleoresins. Rsc Advances 5: 3081-3093.

17. Lorenzo JM, Gonzalez Rodriguez RM, Sánchez M, Amado IR, Franco D (2013) Effects of Natural (Grape Seed and Chestnut Extract) and Synthetic Antioxidants (Buthylatedhydroxytoluene, Bht) on The 
Physical, Chemical, Microbiological and Sensory Characteristics of Dry Cured Sausage "Chorizo". Food Research International 54: 611-620.

18. Ng KS, Tang H, Salley SO (2014) Effect Of Natural And Synthetic Antioxidants On The Oxidative Stability Of Biodiesel. Google Patents.

19. El-Anany AM, Ali RF (2013) Biochemical And Histopathological Effects Of Administration Various Levels Of Pomposia (Syzygium Cumini) Fruit Juice As Natural Antioxidant On Rat Health. J Food Sci Technol 50(3): 487-495.

20. Ho WY, Yeap S, San Liang W, Beh BK, Mohamad N, et al. (2015) In Vitro Antioxidant and In Vivo Hepatoprotective Effect on Ethanol-Mediated Liver Damage Of Spray Dried Vernonia Amygdalina Water Extract. Pak J Pharm Sci 28: 15-22.

21. Godwill EA, Unaegbu M, Esther AU, Gloria OA, Kingsley AN, et al. (2016) Antioxidant And Antidiabetic Activities of The Seed and Leaf Extracts of Chrysophyllumalbidum. Asian Pacific Journal of Tropical Disease 6 : 642-649.

22. Atangwho IJ, Egbung GE, Ahmad M, Yam MF, Asmawi MZ (2013) Antioxidant Versus Anti-Diabetic Properties of Leaves From Vernonia amygdalina Del. Growing In Malaysia. Food Chemi 141(4): 3428-3434.

23. Kahaliw W (2016) Activity Testing, Toxicity Assay and Characterization of Chemical Constituents of Medicinal Plants Used to Treat Tuberculosis In Ethiopian Traditional Medicine.

24. Suh SS, Hwang J, Park M, Park HS, Lee TK (2014) Phenol Content, Antioxidant and Tyrosinase Inhibitory Activity of Mangrove Plants In Micronesia. Asian Pac J Trop Med 7(7): 531-535.

25. Kaur S, Mondal P (2014) Study of Total Phenolic and Flavonoid Content, Antioxidant Activity and Antimicrobial Properties of Medicinal Plants. Journal of Microbiology and Experimentation 1: 5.
26. Podsędek A, Redzynia M, Klewicka E, Koziołkiewicz M (2014) Matrix Effects On The Stability And Antioxidant Activity of Red Cabbage Anthocyanins Under Simulated Gastrointestinal Digestion. Biomed Res Int.

27.Zakaria Y, Azlan NZ, Nik NF, Hassan HM (2016) Phytochemicals and Acute Oral Toxicity Studies of the Aqueous Extract of Vernonia amygdalina From State of Malaysia. Journal of Medicinal Plants 4: 0105.

28. Yagi S, Khiralla A (2016) A Pilot Study of Antioxidant Potential of Endophytic Fungi From Some Sudanese Medicinal Plants. Asian Pac J Trop Med.

29. Kaali R (2016) Traditional Eye Medicines in Tanzania: Products, Health Risk Awareness and Safety Evaluation. Archivos De Medicina 2: 8.

30. Patnaik S, Bhatnagar S (2015) Evaluation of Cytotoxic and Antioxidant Properties and Phytochemical Analysis of Vernonia Anthelmentica. Willid. Leaf Extracts. International Journal of Biosciences and Technology 8(1): 1-4.

31. Thomson I (2015) Rn Asomugha, An Ezejiofor, Pn Okafor and Ii Ijeh. Pakistan Journal of Biological Sciences 18(1): 46-49.

32. Udo I, Akpan G, Ekong N (2015) Cytotoxic Effects of Alcoholic Extracts of 5 Medicinal Plants on Mitosis in Allium Cepa Root Tips After $12 \mathrm{~h}$ Recovery From 24h Treatments. Journal of Medicinal Plants 3: 114117.

33. Arogba S (2014) Phenolics, Antiradical Assay and Cytotoxicity of Processed Mango (Mangifera indica) and Bush Mango (Irvingia gabonensis) Kernels. Nigerian Food Journal 32: 62-72.

\section{Your next submission with Juniper Publishers will reach you the below assets}

- Quality Editorial service

- Swift Peer Review

- Reprints availability

- E-prints Service

- Manuscript Podcast for convenient understanding

- Global attainment for your research

- Manuscript accessibility in different formats

( Pdf, E-pub, Full Text, Audio)

- Unceasing customer service

Track the below URL for one-step submission https://juniperpublishers.com/online-submission.php 